\title{
Soil Test Based Fertilizer Prescription for Targeted Yield of Cabbage (Brassica oleracea Var. Capitata) under Fertigation using Soluble Fertilizers
}

\author{
R. Sundaresh** and P.K. Basavaraja \\ Department of Soil Science and Agricultural Chemistry, AICRP on STCR, College of \\ Agriculture, University of Agricultural Sciences, GKVK, Bangalore-560065, Karnataka, India \\ *Corresponding author
}

\section{A B S T R A C T}

Keywords

STCR-IPNS,

Targeted yield

equation, Cabbage,

Fertigation, Soluble fertilizers

\section{Article Info}

Accepted:

12 October 2019

Available Online:

10 November 2019
Studies on Soil Test Crop Response (STCR) based on Integrated Plant Nutrition System (IPNS) were conducted under fertigation using soluble fertilizers on Alfisols of GKVK, Bengaluru, during kharif2017 to develop fertilizer prescription equations through IPNS using soluble fertilizers under fertigation for the desired yield targets of cabbage (Var. Unnati). Four important basic parameters viz., nutrient requirement (NR), contribution of nutrients from the soil (\%CS), fertilizer $(\% \mathrm{CF})$ and organic matter $(\% \mathrm{C}-\mathrm{OM})$ were computed using field experimental data. Making use of these basic parameters, fertilizer prescription equations were developed for NPK alone (Inorganics) and IPNS for the desired yield targets of cabbage for a range of soil test values. The percent reduction in NPK fertilizers under IPNS also increased with increasing soil fertility levels with reference to NPK. This could be achieved by integrated use of sheep manure with NPK through soluble fertilizers. In comparison to soil testing laboratory (STL) method, STCR dose of fertilizer application through fertigation using soluble fertilizers was found to be superior for precise and efficient use of fertilizer nutrients in soil fertility maintenance by sustaining high productivity.

\section{Introduction}

Sustainable growth in agricultural productivity and production is essential for national, social and economic development in the context of increasing population and assured access to food and nutritional security. Besides, reducing land holdings and increasing the cost of inputs in India leads to the adoption of scientific use of plant nutrient for higher crop productivity. Especially water and nutrients play a very important role in increasing crop productivity. So, precise and judicious use of nutrients and water is important in sustainable agriculture. Fertigation is an attractive technology in modern irrigated agriculture which not only increases yield but also increases fertilizer use efficiency. Fertigation 
has been found as one of the best ways of applying nutrients through the drip irrigation system (Deshmukh and Hardaha, 2014). The drip irrigation system has many advantages. It saves water, machinery and labour, application of fertilizers is more accurate and uniform, finally nutrient uptake by roots is improved. It also proves its superiority over other methods of irrigation due to the direct application of water and nutrients in the vicinity of the root zone which helps in better contact with the root system.

Vegetables impart not only nutritional security but also play a major role in economic viability and fit well into the predominant intensive cropping system prevailing in a different part of our country. Among cole crops, cabbage (Brassica oleraceavar. capitata) is an important crop belongs to the Brassicaceae family.

It is reported to be an excellent source of vitamin $\mathrm{C}$ and $\mathrm{K}$. It contains quercetin an antioxidant that is natural antihistamine that can benefit allergy sufferers. It is a rich source of vitamin $\mathrm{A}$ and $\mathrm{C}$, and consumption of cruciferous vegetables, such as cabbage, is known to reduce the risk of several cancers, especially lung, colon, breast, ovarian and bladder cancer (FAO, 2000). Cabbage is one of the most important vegetable crops which responses to varying level of fertilizer doses which indirectly influence the production

Water soluble fertilizers are the fertilizer nutrients with different grades of NPK fertilizers which are completely soluble in water and characterized by high purity and can be applied in lower doses to get higher benefits. These fertilizers are applied mainly through fertigation. The precise amount of nutrients required by the plants can be easily supplied through water-soluble fertilizers without any wastage. Application of soluble fertilizers enhances nutrient use efficiency of applied nutrients. The most comprehensive approach of fertilizer application using soil test values, nutrient requirement of the crop, contribution of nutrients from soil, manures, fertilizers and fixing yield-targets is possible only through Soil Test Crop Response (STCR) approach.

Soil test based fertilizer recommendations results in efficient use of fertilizer and sustaining soil fertility (Ramamoorthy et al., 1967). This approach is unique as this not only indicates soil test based fertilizer dose but also the level of yield that can be obtained if appropriate practices are followed in raising the crop.

Development of soil test based fertilizer prescription equation by using soluble fertilizer through fertigation was not done in India so far. Hence, a present study has been taken on Alfisols of Eastern dry zone of Karnataka for cabbage crop under fertigation using water-soluble fertilizers to develop a STCR targeted yield equation with a farmer's friendly ready reckoner.

\section{Materials and Methods}

A field experiment was conducted with cabbage (Brassica oleracea var. capitata) variety Unnati as test crop during kharif 201718 on Kandicpaleustalfs at Zonal Agriculture Research Station, GKVK, Bengaluru to develop the targeted yield equations by following the standard procedure as outlined by Ramamoorthy et al., (1967). The surface soil (0-20 cm deep) of the experimental field was red soil, well-drained sandy clay loam texture with $\mathrm{pH} 5.90$ and electrical conductivity of $0.32 \mathrm{dSm}^{-1}$. The Initial soil organic carbon was 0.51 percent, available alkaline potassium permanganate $\left(\mathrm{KMnO}_{4}-\mathrm{N}\right)$ nitrogen, available Bray's phosphorus $\left(\mathrm{P}_{2} \mathrm{O}_{5}\right)$ and ammonium acetate extractable potassium $\left(\mathrm{K}_{2} \mathrm{O}\right)$ were 232.77 (low), 176.82 (high) and 
228.60 (medium) $\mathrm{kg} \mathrm{ha}^{-1}$ respectively. Prior to main experimentation with cabbage crop, fertility gradient experiment was conducted to develop wide variation in NPK fertility status in the same field by dividing the experimental field into three rectangular strips (I, II and III strips).To create variation in soil fertility levels, no fertilizers (only $5 \mathrm{t}$ FYM) in I strip, standard dose of $\mathrm{N}$ and $\mathrm{P}_{2} \mathrm{O}_{5}$ without $\mathrm{P}_{2} \mathrm{O}_{5}$ (75,00and $100 \mathrm{~kg} \mathrm{NPK} \mathrm{ha}^{-1}$ ) in II strip and double dose of $\mathrm{N}$ and $\mathrm{P}_{2} \mathrm{O}_{5}$ without $\mathrm{P}_{2} \mathrm{O}_{5}$ (150, 0.00 and $\left.200 \mathrm{~kg} \mathrm{NPK} \mathrm{ha}^{-1}\right)$ in III strip was applied. An exhaustive crop of fodder maize (variety- African tall) was grown to enable the applied fertilizer nutrients to undergo transformation in the soil by plant and microbes. Fodder maize was harvested at 60 days after sowing (DAS) and recorded the fodder yield. Similarly, soil samples were also collected and analyzed for major nutrients to check the development of fertility gradient.

After developing the fertility gradient in the same plot, main experiment was conducted with cabbage as a test crop by dividing each fertility strip into three blocks of manure $\left(\mathrm{F}_{0^{-}}\right.$ No sheep manure, $F_{1}$ - recommended dose of sheep manure, $\mathrm{F}_{2}-$ Double dose of sheep manure), each of these manure blocks were divided into 8 subplots by considering seven different NPK combinations +1 absolute control. So, a total of 21 treatments of NPK combinations and 3 controls were imposed in each strip and making a total of 72 plots from three strips (Table 1). From all these plots, initial soil samples were collected $(0-20 \mathrm{~cm})$ for NPK analysis before imposing sheep manure and NPK treatments.

Cabbage crop was grown with four levels of $\mathrm{N}$ $\left(0,75,150\right.$ and $\left.225 \mathrm{~kg} \mathrm{ha}^{-1}\right), \mathrm{P}_{2} \mathrm{O}_{5}(0,50,100$ and $\left.150 \mathrm{~kg} \mathrm{ha}^{-1}\right)$ and $\mathrm{K}_{2} \mathrm{O}(0,62.50,125$ and $190 \mathrm{~kg} \mathrm{ha}^{-1}$ ) and three levels of sheep manure $\left(0,25\right.$ and $\left.40 \mathrm{t} \mathrm{ha}^{-1}\right)$. Out of which $21 \mathrm{NPK}$ combinations were used in the experiment by taking 7 NPK treatments +1 control in each manure blocks. Then each of these treatments combinations was randomized in the other two strips and also in the manure blocks.

\section{Fertigation schedule}

Thirty percent of soluble fertilizer corresponding to four levels of N, P and $\mathrm{K}$ was applied at the time of transplanting of cabbage. Remaining 70 percent of the corresponding fertilizer dose was applied 7 times at 10 percent dose at 8 days interval through drip fertigation in all the treated plots.

All fertilizer application through fertigation process was completed before 60 days after transplanting.

The crop was raised as per the standard package of practices and taken care of appropriate plant protection measures. Fully grown cabbage heads were harvested at 90 days after transplanting and head yield per plot was recorded from all the plots and expressed in $\mathrm{t} \mathrm{ha}^{-1}$. Representative cabbage plant samples collected from all the plots were dried at $60^{\circ} \mathrm{C}$ to attain a constant weight, ground and analyzed for nitrogen, phosphorus and potassium contents by following standard procedures outlined by Jackson (1973) and total nutrient uptake was computed. Initial soil data, cabbage yield and nutrient uptake by cabbage crop were used for calculating the four important basic parameters viz., Nutrient requirement- nutrient required to produce a quintal of cabbage yield (NR), percent contribution of nutrients from soil (\% CS), percent contribution of nutrients from fertilizers $(\% \mathrm{CF})$ and percent contribution of nutrients from organic matter $(\mathrm{C}-\mathrm{OM})$ by using following formulae (Ramamoorthy et al., 1967)

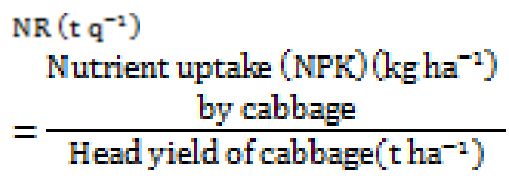



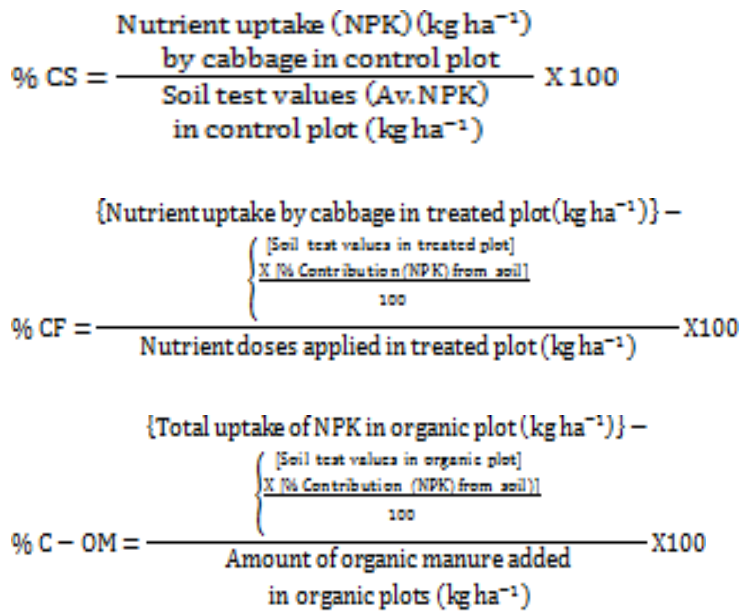

These basic parameters were transformed into simple, workable fertilizer adjustment equations for calculating specific yield target based on soil test values by following the procedure of Ramamoorthy et al., (1967) as follows, These parameters are related to viz., NR with yield (y), \% CS with soil nutrients, \% $\mathrm{CF}$ with fertilizer nutrients and \% C-OM with organic matter, as follows, $\mathrm{NR}(\mathrm{y})=(\% \mathrm{CS})$ $(\mathrm{SN})+(\% \mathrm{CF})(\mathrm{FN})+[(\% \mathrm{C}-\mathrm{OM})(\mathrm{OM})]$

\section{Results and Discussion}

Initially available NPK status, grain yield, and nutrient uptake

The data on initial soil available nutrient status was presented in table 2 . The initial soil test values revealed that the available nitrogen ranged from $201.36 \mathrm{~kg} \mathrm{ha}^{-1}$ to $325.76 \mathrm{~kg} \mathrm{ha}^{-1}$ in I strip, $215.16 \mathrm{~kg} \mathrm{ha}^{-1}$ to $265.64 \mathrm{~kg} \mathrm{ha}^{-1}$ in II strip and $208.08 \mathrm{~kg} \mathrm{ha}^{-1}$ to $307.36 \mathrm{~kg} \mathrm{ha}^{-1}$ in III strip. However, mean values of available $\mathrm{N}$ was $252.95 \mathrm{~kg} \mathrm{ha}^{-1}, 248.09 \mathrm{~kg} \mathrm{ha}^{-1}, 236.43 \mathrm{~kg}$ $\mathrm{ha}^{-1}$ in I, II and III strips, respectively. The available $\mathrm{P}_{2} \mathrm{O}_{5}$ ranged from $50.84 \mathrm{~kg} \mathrm{ha}^{-1}$ to $371.12 \mathrm{~kg} \mathrm{ha}^{-1}, 176.66 \mathrm{~kg} \mathrm{ha}^{-1}$ to $388.91 \mathrm{~kg}$ $\mathrm{ha}^{-1}, 190.08 \mathrm{~kg} \mathrm{ha}^{-1}$ to $598.80 \mathrm{~kg} \mathrm{ha}^{-1}$ in I, II and III strips respectively. Mean value of available $\mathrm{P}_{2} \mathrm{O}_{5}$ was $163.53 \mathrm{~kg} \mathrm{ha}^{-1}, 222.16 \mathrm{~kg}$ $\mathrm{ha}^{-1}$ and $380.98 \mathrm{~kg} \mathrm{ha}^{-1}$ of $\mathrm{P}_{2} \mathrm{O}_{5}$ in I, II and III strips respectively. Available $\mathrm{K}_{2} \mathrm{O}$ ranged from $133.20 \mathrm{~kg} \mathrm{ha}^{-1}$ to $208.80 \mathrm{~kg} \mathrm{ha}^{-1}$ with a mean value of $163.48 \mathrm{~kg} \mathrm{ha}^{-1}$ in Istrip, 182.40 $\mathrm{kg} \mathrm{ha}^{-1}$ to $346.80 \mathrm{~kg} \mathrm{ha}^{-1}$ with a mean value of $243.90 \mathrm{~kg} \mathrm{ha}^{-1}$ in II strip and $314.40 \mathrm{~kg} \mathrm{ha}^{-1}$ to $434.40 \mathrm{~kg} \mathrm{ha}^{-1}$ with a mean value of $377.32 \mathrm{~kg}$ $\mathrm{ha}^{-1}$ in III strip.

Range and mean values of cabbage yield and NPK uptake by cabbage crop (Table 2) revealed that the highest cabbage yield and nutrient uptake with respect to NPK were recorded from strip I followed by strip II and lowest in strip III. Mean cabbage yield from overall plots were in the descending order of $46.97,42.11$ and $36.27 \mathrm{~kg} \mathrm{ha}^{-1}$ in strip I, II and III, respectively.

The nitrogen uptake in strip I, II and III ranged respectively from $12.71 \mathrm{~kg} \mathrm{ha}^{-1} \mathrm{~N}$ to $158.19 \mathrm{~kg}$ ha $^{-1} \mathrm{~N}, 13.28 \mathrm{~kg} \mathrm{ha}^{-1} \mathrm{~N}$ to $153.93 \mathrm{~kg} \mathrm{ha}^{-1} \mathrm{~N}$ and $28.98 \mathrm{~kg} \mathrm{ha}^{-1} \mathrm{~N}$ to $116.63 \mathrm{~kg} \mathrm{ha}^{-1} \mathrm{~N}$ with the mean values of $98.15 \mathrm{~N} \mathrm{~kg} \mathrm{ha}^{-1}, 89.63 \mathrm{~kg}$ $\mathrm{ha}^{-1} \mathrm{~N}$ and $80.26 \mathrm{~kg} \mathrm{ha}^{-1} \mathrm{~N}$. The phosphorus uptake ranged from $4.52 \mathrm{~kg} \mathrm{ha}^{-1} \mathrm{P}_{2} \mathrm{O}_{5}$ to 87.54 $\mathrm{kg} \mathrm{ha}^{-1} \mathrm{P}_{2} \mathrm{O}_{5}$ with a mean of $42.59 \mathrm{~kg} \mathrm{ha}^{-1} \mathrm{P}_{2} \mathrm{O}_{5}$ in strip I,

In strip II it ranged from $6.24 \mathrm{~kg} \mathrm{ha}^{-1} \mathrm{P}_{2} \mathrm{O}_{5}$ to $80.58 \mathrm{~kg} \mathrm{ha}^{-1} \mathrm{P}_{2} \mathrm{O}_{5}$ with a mean of $41.48 \mathrm{~kg}$ $\mathrm{ha}^{-1} \mathrm{P}_{2} \mathrm{O}_{5}$ and from $12.83 \mathrm{~kg} \mathrm{ha}^{-1} \mathrm{P}_{2} \mathrm{O}_{5}$ to 83.84 $\mathrm{kg} \mathrm{ha}{ }^{-1} \mathrm{P}_{2} \mathrm{O}_{5}$ with a mean of $38.92 \mathrm{~kg} \mathrm{ha}^{-1} \mathrm{P}_{2} \mathrm{O}_{5}$ in strip III. The potassium uptake ranged from $14.26 \mathrm{~kg} \mathrm{ha}^{-1} \mathrm{~K}_{2} \mathrm{O}$ to $229.91 \mathrm{~kg} \mathrm{ha}^{-1} \mathrm{~K}_{2} \mathrm{O}, 16.32$ $\mathrm{kg} \mathrm{ha}^{-1} \mathrm{~K}_{2} \mathrm{O}$ to $183.33 \mathrm{~kg} \mathrm{ha}^{-1} \mathrm{~K}_{2} \mathrm{O}$ and 43.33 $\mathrm{kg} \mathrm{ha}^{-1} \mathrm{~K}_{2} \mathrm{O}$ to $185.62 \mathrm{~kg} \mathrm{ha}^{-1} \mathrm{~K}_{2} \mathrm{O}$ with mean values of $127.27 \mathrm{~kg} \mathrm{ha}^{-1} \mathrm{~K}_{2} \mathrm{O}, 114.57 \mathrm{~kg} \mathrm{ha}^{-1}$ $\mathrm{K}_{2} \mathrm{O}$ and $111.64 \mathrm{~kg} \mathrm{ha}^{-1} \mathrm{~K}_{2} \mathrm{O}$ in strip I, II and III, respectively.

The above results clearly showed that there exists a wide variability among soil test values, grain yield and nutrient uptake among the strips and treatments which is a prerequisite for calculating the basic parameters and to develop the fertilizer prescription equations for calibrating the fertilizer doses for certain specific yield target. Uma Devi (2005) reported that there should be an 
existence of operational ranges of available $\mathrm{N}$, $\mathrm{P}$ and $\mathrm{K}$ for carrot crop on Ultisol.

\section{Basic parameters}

The basic parameters required for developing fertilizer prescription equations for cabbage are nutrient requirement (NR) in $\mathrm{kg}$ per ton of cabbage yield, percent contribution of available NPK from soil (\% CS), fertilizers (\% $\mathrm{CF}$ ) and organic manure (\% C-OM). By making use of basic data obtained from the main experiment viz., Initial soil test values for available $\mathrm{N}, \mathrm{P}_{2} \mathrm{O}_{5}$ and $\mathrm{K}_{2} \mathrm{O}$, doses of fertilizer $\mathrm{N}, \mathrm{P}_{2} \mathrm{O}_{5}$ and $\mathrm{K}_{2} \mathrm{O}$ applied cabbage yield, total uptake of $\mathrm{N}, \mathrm{P}_{2} \mathrm{O}_{5}$ and $\mathrm{K}_{2} \mathrm{O}$, the basic parameters viz. NR, CS, CF and C-OM were computed.

Nutrient requirement to produce one ton of cabbage under IPNS- STCR approach was computed as $2.143 \mathrm{~kg}$ of $\mathrm{N}, 1.151 \mathrm{~kg}$ of $\mathrm{P}_{2} \mathrm{O}_{5}$ and $3.423 \mathrm{~kg}$ of $\mathrm{K}_{2} \mathrm{O}$ (Table 3 ). This clearly showed that potassium requirement is highest followed by nitrogen and phosphorus for cabbage to produce one-ton yield.

The contribution of nutrients from fertilizer was computed as 51.505 percent, 43.045 percent and 79.018 percent of $\mathrm{N}, \mathrm{P}_{2} \mathrm{O}_{5}$ and $\mathrm{K}_{2} \mathrm{O}$ respectively towards the cabbage yield. Among the three major nutrients, order of percentage contribution of fertilizer nutrient to cabbage yield was observed as $K>N>P$. Contribution of soil nutrients towards cabbage yield was 6.225 percent, 5.371 percent and 8.844 percent of $\mathrm{N}, \mathrm{P}_{2} \mathrm{O}_{5}$ and $\mathrm{K}_{2} \mathrm{O}$ respectively. This data evidently confirms that the contribution of fertilizers NPK was higher than that of soil contribution of NPK towards cabbage yield. A similar trend of nutrient requirement for $\mathrm{N}, \mathrm{P}_{2} \mathrm{O}_{5}$ and $\mathrm{K}_{2} \mathrm{O}$ were reported by Smitha et al., (2010) for Cabbage. The findings of the present study are closely accorded with those reported by Basavaraja et al., (2017) in finger millet and Meena et al.,
(2001) in onion crop. This higher contribution of $\mathrm{K}$ might be due to the interaction effect of higher doses of $\mathrm{N}, \mathrm{P}$ and the primary effect of starter $\mathrm{K}$ doses in the treated plots, which caused the release of soil potassium form, resulting in the higher $\mathrm{K}$ uptake from the native soil sources by the crop (Ray et al., 2000). The contribution from fertilizers was higher than the soil for all the three nutrients. The contribution of nutrients towards the growth of the crop and in turn towards yield was higher from fertilizers than that of soil for all the three nutrients $\left(\mathrm{N}, \mathrm{P}_{2} \mathrm{O}_{5}\right.$ and $\left.\mathrm{K}_{2} \mathrm{O}\right)$.

The percent contribution of NPK nutrients from the organic manures $(\mathrm{C}-\mathrm{OM})$ to the total uptake was computed from the organic manure applied plots $\left(\mathrm{F}_{1} @ 25\right.$ t ha ${ }^{-1}$ and F2 @ $40 \mathrm{t} \mathrm{ha}^{-1}$ ).

The contribution of nutrients from organic matter was computed as $0.858 \%, 0.256 \%$ and $0.870 \%$ of $\mathrm{N}, \mathrm{P}_{2} \mathrm{O}_{5}$ and $\mathrm{K}_{2} \mathrm{O}$ respectively.

The results of the study are in conformity with the work of Basavaraja et al., 2017 for finger millet, Vijayalakshmi (2008) for radish and Santhi et al., (2011) for beetroot on Typic haplustalf.

\section{Fertilizer prescription equations for cabbage crop under fertigation using soluble fertilizers}

By relating the basic parameters obtained from the main experiment, soil test based fertilizer prescription equations for desired targeted yield of cabbage were formulated as below

\section{NPK alone - (Inorganic equation)}

$\mathrm{F} . \mathrm{N}=4.4750 \mathrm{~T}-0.1342 \mathrm{STV}\left(\mathrm{KMnO}_{4}-\mathrm{N}\right)$

F. $\mathrm{P}_{2} \mathrm{O}_{5}=3.5822 \mathrm{~T}-0.1954$ (Bray's $-\mathrm{P}_{2} \mathrm{O}_{5}$ )

F. $\mathrm{K}_{2} \mathrm{O}=3.8005 \mathrm{~T}-0.1140$ (Am. Acetate $\mathrm{K}_{2} \mathrm{O}$ ) 
NPK with organic matter - [Integrated plant nutrient supply (IPNS) equation]

F. $\mathrm{N}=4.1600 \mathrm{~T}-0.1209 \mathrm{STV}\left(\mathrm{KMnO}_{4}-\mathrm{N}\right)-$ $0.858 \mathrm{OM}$

F. $\mathrm{P}_{2} \mathrm{O}_{5}=2.6736 \mathrm{~T}-0.1248$ (Bray's $\left.-\mathrm{P}_{2} \mathrm{O}_{5}\right)$ $0.256 \mathrm{OM}$

F. $\mathrm{K}_{2} \mathrm{O}=4.3324 \mathrm{~T}-0.1119$ (Am. Acetate $\left.\mathrm{K}_{2} \mathrm{O}\right)-0.870 \mathrm{OM}$

Where, F.N, F. $\mathrm{P}_{2} \mathrm{O}_{5}$ and $\mathrm{F} . \mathrm{K}_{2} \mathrm{O}$ are fertilizer $\mathrm{N}, \mathrm{P}_{2} \mathrm{O}_{5}$ and $\mathrm{K}_{2} \mathrm{O}$ in $\mathrm{kg} \mathrm{ha}^{-1}$ respectively; $\mathrm{T}$ is the yield target in $\mathrm{t} \mathrm{ha}^{-1}$; $\mathrm{SN}$, SP and $\mathrm{SK}$ are Alkaline $\mathrm{KMnO}_{4}-\mathrm{N}, \quad$ Bray's $-\mathrm{P}_{2} \mathrm{O}_{5}$ and $\mathrm{NH}_{4} \mathrm{OAc}-\mathrm{K}_{2} \mathrm{O}$ in kg ha ${ }^{-1}$ respectively and $\mathrm{OM}$ is organic matter in tha ${ }^{-1}$. Using the above equations, a farmer-friendly ready reckoner was formulated for a range of soil test values and desired yield targets of cabbage with soluble fertilizers alone as well as in combination with locally available sheep manure (Table 4).

Fertilizer response is described asa functional relationship between an increase in crop yield and fertilizers added. It can be expressed graphically or algebraically by an equation. Milap Chand et al., (2006) noticed the superiority of targeted yield concept over other approaches of fertilizer prescription for different crops as it gave higher yields, net benefit and optimal economic returns. Kasthuri and Natesan (2009) documented the formulation of fertilizer prescription equation for cauliflower crop through STCR targeted yield approach. The yield targets were achieved within reasonable limits when the fertilizer was applied on soil test basis in the majority of the crops thus establishing the utility of the prescription equations for recommending soil test based fertilizer application to the farmers. In the present investigation, the data evidently revealed that the fertilizer $\mathrm{N}, \mathrm{P}_{2} \mathrm{O}_{5}$ and $\mathrm{K}_{2} \mathrm{O}$ requirements decreased with increase in soil test values and increased with increase in yield targets.

Fertilizer prescription under IPNS for desired yield target of cabbage under fertigation using soluble fertilizers

A ready reckoner (Table 4) was prepared using these equations for a range of soil test values and for a yield target of $33 \mathrm{tha}^{-1}$ for cabbage crop. For achieving a yield target of $33 \mathrm{t} \mathrm{ha}^{-1}$ of cabbage with a soil test value of $250 \mathrm{~kg} \mathrm{ha}^{-1}$ of $\mathrm{N}, 21 \mathrm{~kg} \mathrm{ha}^{-1}$ of $_{2} \mathrm{O}_{5}$ and $240 \mathrm{~kg}$ ha ${ }^{-1}$ of $\mathrm{K}_{2} \mathrm{O}$, the fertilizer $\mathrm{N}, \mathrm{P}_{2} \mathrm{O}_{5}$ and $\mathrm{K}_{2} \mathrm{O}$ doses required through soluble fertilizers are $114.13 \mathrm{~kg} \mathrm{ha}^{-1}, 114.10 \mathrm{~kg} \mathrm{ha}^{-1}$ and $98.04 \mathrm{~kg} \mathrm{ha}^{-1}$ in NPK alone (Inorganics) and $85.61 \mathrm{~kg} \mathrm{ha}^{-1}$, $79.22 \mathrm{~kg} \mathrm{ha}{ }^{-1}$ and $95.35 \mathrm{~kg} \mathrm{ha}^{-1}$ in IPNS approach, where sheep manure was applied at $25 \mathrm{t} \mathrm{ha}^{-1}$ along with soluble NPK fertilizers.

Similarly, when the soil test values are560.00, 52.00 and $300.00 \mathrm{~kg} \mathrm{ha}^{-1}$ for $\mathrm{N}, \mathrm{P}_{2} \mathrm{O}_{5}$ and $\mathrm{K}_{2} \mathrm{O}$ respectively, the fertilizer NPK nutrients through soluble fertilizers required for the same targeted yield $\left(33 \mathrm{t} \mathrm{ha}^{-1}\right)$ are 48.15, 108.44 and $87.64 \mathrm{~kg} \mathrm{ha}^{-1}$ respectively with $25 \mathrm{t}$ $\mathrm{ha}^{-1}$ of FYM.

The variation in nutrients application to be made are $4.47 \mathrm{~kg} \mathrm{~N} \mathrm{ha}^{-1}, 3.58 \mathrm{~kg} \mathrm{P}_{2} \mathrm{O}_{5} \mathrm{ha}^{-1}$ and $3.80 \mathrm{~kg} \mathrm{~K}_{2} \mathrm{O} \mathrm{ha}^{-1}$ to increase or decrease one ton $\left(10 \pm 1 \mathrm{tha}^{-1}\right)$ of cabbage yield in NPK alone (inorganic equation), whereas, in STCRIPNS equation $4.16 \mathrm{~kg} \mathrm{~N} \mathrm{ha}^{-1}, 2.67 \mathrm{~kg} \mathrm{P}_{2} \mathrm{O}_{5}$ $\mathrm{ha}^{-1}$ and $4.33 \mathrm{~kg} \mathrm{~K}_{2} \mathrm{O} \mathrm{ha}^{-1}$ to increase or decrease one ton $\left(10 \pm 1 \mathrm{t} \mathrm{ha}^{-1}\right)$ of cabbage yield from values of fertilizer nutrients required to produce specific yield target. Similar variations in nutrient doses were recorded by Basavaraja et al., (2017) for dry land finger millet with a targeted yield of 35 qha $^{-1}$. 
Table.1 Treatment details of the main experiment with cabbage as a test crop

\begin{tabular}{|c|c|c|c|c|c|}
\hline \multicolumn{2}{|c|}{ I } & \multicolumn{2}{c|}{ II } & \multicolumn{2}{c|}{ III } \\
\hline SI. No. & $\mathbf{F}_{\mathbf{0}}$ & Sl. No. & $\mathbf{F}_{\mathbf{1}}$ & Sl. No. & $\mathbf{F}_{\mathbf{1}}$ \\
\hline $\mathbf{1 .}$ & $3-1-1$ & 25. & $2-2-3$ & 49. & $2-2-2$ \\
\hline $\mathbf{2 .}$ & $2-2-3$ & 26. & $0-0-0$ & 50. & $0-0-0$ \\
\hline $\mathbf{3 .}$ & $0-2-2$ & 27. & $0-2-2$ & 51. & $3-2-2$ \\
\hline $\mathbf{4 .}$ & $0-0-0$ & 28. & $2-1-1$ & 52. & $2-2-0$ \\
\hline $\mathbf{5 .}$ & $2-1-1$ & 29. & $2-2-1$ & 53. & $2-3-2$ \\
\hline $\mathbf{6 .}$ & $1-1-1$ & 30. & $1-2-1$ & 54. & $3-3-1$ \\
\hline $\mathbf{7 .}$ & $1-2-1$ & 31. & $3-1-1$ & 55. & $2-1-2$ \\
\hline $\mathbf{8 .}$ & $2-2-1$ & 32. & $1-1-1$ & 56. & $1-2-2$ \\
\hline & $\mathbf{F}_{\mathbf{1}}$ & & $\mathbf{F}_{\mathbf{0}}$ & & $\mathbf{F}_{\mathbf{2}}$ \\
\hline $\mathbf{9 .}$ & $3-2-3$ & 33. & $2-2-0$ & 57. & $3-1-1$ \\
\hline $\mathbf{1 0 .}$ & $3-2-1$ & 34. & $3-3-1$ & 58. & $2-2-3$ \\
\hline $\mathbf{1 1 .}$ & $1-1-2$ & 35. & $2-2-2$ & 59. & $1-1-1$ \\
\hline $\mathbf{1 2 .}$ & $2-0-2$ & 36. & $1-2-2$ & 60. & $0-2-2$ \\
\hline $\mathbf{1 3 .}$ & $2-3-3$ & 37. & $3-2-2$ & 61. & $0-0-0$ \\
\hline $\mathbf{1 4 .}$ & $0-0-0$ & 38. & $2-3-2$ & 62. & $1-2-1$ \\
\hline $\mathbf{1 5 .}$ & $3-3-2$ & 39. & $2-1-2$ & 63. & $2-2-1$ \\
\hline $\mathbf{1 6 .}$ & $3-3-3$ & 40. & $0-0-0$ & 64. & $2-1-1$ \\
\hline & $\mathbf{F}_{\mathbf{2}}$ & & $\mathbf{F}_{\mathbf{2}}$ & & $\mathbf{F}_{\mathbf{0}}$ \\
\hline $\mathbf{1 7 .}$ & $1-2-2$ & 41. & $3-3-2$ & 65. & $0-0-0$ \\
\hline $\mathbf{1 8 .}$ & $3-3-1$ & 42. & $0-0-0$ & 66. & $1-1-2$ \\
\hline $\mathbf{1 9 .}$ & $3-2-2$ & 43. & $2-3-3$ & 67. & $3-2-3$ \\
\hline $\mathbf{2 0 .}$ & $0-0-0$ & 44. & $1-1-2$ & 68. & $2-3-3$ \\
\hline $\mathbf{2 1 .}$ & $2-3-2$ & 45. & $3-3-3$ & 69. & $3-2-1$ \\
\hline $\mathbf{2 2 .}$ & $2-2-2$ & 46. & $3-2-3$ & 70. & $3-3-3$ \\
\hline $\mathbf{2 3 .}$ & $2-1-2$ & 47. & $2-0-2$ & 71. & $3-3-2$ \\
\hline $\mathbf{2 4 .}$ & $2-2-0$ & 48. & $3-2-1$ & 72. & $2-0-2$ \\
\hline
\end{tabular}

Note: $0=$ No fertilizers.

$1=$ Half of the RDF.

$2=$ Recommended dose of fertilizers (150: 100: $125 \mathrm{~kg} \mathrm{NPK} \mathrm{ha}^{-1}$ ).

$3=$ One and half times RDF.

$\mathrm{I}=$ Low fertility strip, $\mathrm{II}=$ medium fertility strip, $\mathrm{III}=$ High fertility strip . 
Table.2 Initial soil available NPK, cabbage yield and NPK uptake by cabbage crop under fertigation in various strips

\begin{tabular}{|c|c|c|c|c|c|c|c|c|}
\hline \multirow[t]{2}{*}{ Strip } & & \multicolumn{3}{|c|}{ Initial soil test vales $\left(\mathrm{kg} \mathrm{ha}^{-1}\right)$} & \multirow{2}{*}{$\begin{array}{c}\begin{array}{c}\text { Cabbage } \\
\text { yield }\end{array} \\
\left(\mathrm{t} \mathrm{ha}^{-1}\right)\end{array}$} & \multicolumn{3}{|c|}{ Uptake (kg ha $\left.{ }^{-1}\right)$} \\
\hline & & $\underset{\mathbf{N}}{\mathrm{KMnO}_{4-}^{-}}$ & $\begin{array}{c}\text { Bray's } \\
\mathbf{P}_{2} \mathbf{O}_{5}\end{array}$ & $\begin{array}{c}\mathrm{NH}_{4} \mathrm{OAc}- \\
\mathrm{K}_{2} \mathrm{O}\end{array}$ & & $\mathbf{N}$ & $\mathbf{P}_{2} \mathrm{O}_{5}$ & $\mathrm{~K}_{2} \mathrm{O}$ \\
\hline \multirow[t]{3}{*}{ I } & Min. & 201.36 & 50.84 & 133.20 & 7.23 & 12.71 & 4.52 & 14.26 \\
\hline & Max. & 325.76 & 371.12 & 208.80 & 69.05 & 158.19 & 87.54 & 229.91 \\
\hline & Mean & 252.95 & 163.53 & 163.48 & 46.97 & 98.15 & 42.59 & 127.27 \\
\hline \multirow[t]{3}{*}{ II } & Min. & 215.16 & 176.66 & 182.40 & 8.86 & 13.28 & 6.24 & 16.32 \\
\hline & Max. & 265.64 & 388.91 & 346.80 & 63.15 & 153.93 & 80.58 & 183.33 \\
\hline & Mean & 248.09 & 222.16 & 243.90 & 42.11 & 89.63 & 41.48 & 114.57 \\
\hline \multirow[t]{3}{*}{ III } & Min. & 208.08 & 190.08 & 314.40 & 18.04 & 28.98 & 12.83 & 43.33 \\
\hline & Max. & 307.36 & 598.80 & 434.40 & 52.57 & 116.63 & 83.84 & 185.62 \\
\hline & Mean & 236.43 & 380.98 & 377.32 & 36.27 & 80.26 & 38.92 & 111.64 \\
\hline
\end{tabular}

Table.3 Nutrient requirement and percent contribution of nutrients from soil, soluble fertilizers and organic matter for irrigated cabbage under IPNS -STCR approach

\begin{tabular}{|c|c|c|c|}
\hline Parameters & \multicolumn{3}{|c|}{ Basic data } \\
\cline { 2 - 4 } & $\mathbf{N}$ & $\mathbf{P}_{2} \mathbf{O}_{\mathbf{5}}$ & $\mathbf{K}_{\mathbf{2}} \mathbf{O}$ \\
\hline Nutrient requirement (NR) (kg t $\left.\mathbf{- 1}^{-\mathbf{}}\right)$ & 2.143 & 1.151 & 3.423 \\
\hline Contribution from soil (CS) (\%) & 6.225 & 5.371 & 8.844 \\
\hline Contribution from fertilizers (CF) (\%) & 51.505 & 43.045 & 79.018 \\
\hline Contribution from organic matter (C-OM) (\%) & 0.858 & 0.256 & 0.870 \\
\hline
\end{tabular}


Table.4 Ready reckoner for soil test based fertilizer nutrient recommendations for a yield target of $33 \mathrm{t} \mathrm{ha}^{-1}$ of cabbage with and without sheep manure.

\begin{tabular}{|c|c|c|c|c|c|c|c|c|}
\hline $\begin{array}{c}\text { STV } \\
\mathrm{KMnO}_{4-} \\
\mathrm{N} \\
\left(\mathrm{kg} \mathrm{ha}^{-1}\right)\end{array}$ & $\begin{array}{c}\text { Only } \\
\text { inorganics } \\
\text { F. N. } \\
\text { Req. }\end{array}$ & $\begin{array}{c}\text { With } 25 \mathrm{t} \\
\text { ha }^{-1} \text { sheep } \\
\text { manure } \\
\text { F. N. Req. }\end{array}$ & $\begin{array}{c}\text { STV } \\
\mathrm{P}_{2} \mathrm{O}_{5} \\
\left(\mathrm{~kg} \mathrm{ha}^{-1}\right)\end{array}$ & 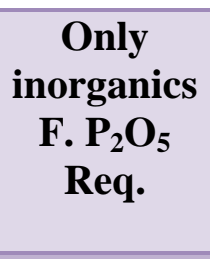 & $\begin{array}{c}\text { With } 25 \mathrm{t} \\
\text { ha }^{-1} \text { sheep } \\
\text { manure } \\
\text { F. } \mathrm{P}_{2} \mathrm{O}_{5} \\
\text { Req. }\end{array}$ & $\begin{array}{c}\text { STV } \\
\mathrm{K}_{2} \mathrm{O} \\
(\mathbf{k g} \\
\left.\mathrm{ha}^{-1}\right)\end{array}$ & $\begin{array}{c}\text { Only } \\
\text { inorganics } \\
\text { F. } \\
\mathrm{K}_{2} \text { OReq. }\end{array}$ & $\begin{array}{c}\text { With } 25 \mathrm{t} \\
\text { ha }^{-1} \text { sheep } \\
\text { manure } \\
\text { F. K2O } \\
\text { Req. }\end{array}$ \\
\hline 250 & 114.13 & 85.61 & 15 & 115.28 & 79.97 & 110 & 112.86 & 108.90 \\
\hline 260 & 112.78 & 84.41 & 17 & 114.88 & 79.72 & 120 & 111.72 & 107.78 \\
\hline 280 & 110.10 & 81.99 & 19 & 114.49 & 79.47 & 125 & 111.15 & 107.22 \\
\hline 290 & 108.76 & 80.78 & 21 & 114.10 & 79.22 & 130 & 110.58 & 106.66 \\
\hline 300 & 107.42 & 79.57 & 23 & 113.71 & 78.97 & 140 & 109.44 & 105.54 \\
\hline 320 & 104.73 & 77.15 & 25 & 113.32 & 78.72 & 150 & 108.30 & 104.42 \\
\hline 340 & 102.05 & 74.74 & 30 & 112.34 & 78.10 & 160 & 107.16 & 103.30 \\
\hline 400 & 94.00 & 67.49 & 32 & 111.95 & 77.85 & 170 & 106.02 & 102.18 \\
\hline 440 & 88.63 & 62.65 & 35 & 111.37 & 77.47 & 180 & 104.88 & 101.06 \\
\hline 480 & 83.26 & 57.82 & 38 & 110.78 & 77.10 & 200 & 102.60 & 98.83 \\
\hline 520 & 77.89 & 52.98 & 41 & 110.19 & 76.73 & 220 & 100.32 & 96.59 \\
\hline 560 & 72.52 & 48.15 & 44 & 109.61 & 76.35 & 240 & 98.04 & 94.35 \\
\hline \multirow[t]{7}{*}{600} & 67.16 & 43.31 & 46 & 109.22 & 76.10 & 260 & 95.76 & 92.11 \\
\hline & & & 47 & 109.02 & 75.98 & 280 & 93.48 & 89.87 \\
\hline & & & 50 & 108.44 & 75.60 & 300 & 91.20 & 87.64 \\
\hline & & & 52 & 108.05 & 75.35 & 320 & 88.92 & 85.40 \\
\hline & & & 54 & 107.65 & 75.10 & 340 & 86.64 & 83.16 \\
\hline & & & 58 & 106.87 & 74.60 & 440 & 75.24 & 71.97 \\
\hline & & & 62 & 106.09 & 74.10 & & & \\
\hline \multicolumn{9}{|c|}{$\begin{array}{l}\text { To increase or decrease the yield target by one } \mathrm{tha}^{-1} \text {, the variations to be made in the fertilizer } \\
\text { recommendations are as follows } \\
\text { For NPK alone (Inorganics): } N= \pm 4.47 \mathrm{~kg} \mathrm{ha}^{-1} \quad \mathrm{P}_{2} \mathrm{O}_{5}= \pm 3.58 \mathrm{~kg} \mathrm{ha}^{-1} \quad \mathrm{~K}_{2} \mathrm{O}= \pm 3.80 \mathrm{~kg} \mathrm{ha}^{-1} \\
\text { For IPNS equation: } \mathrm{N}= \pm 4.16 \mathrm{~kg} \mathrm{ha}^{-1} \quad \mathrm{P}_{2} \mathrm{O}_{5}= \pm 2.67 \mathrm{~kg} \mathrm{ha}^{-1} \quad \mathrm{~K}_{2} \mathrm{O}= \pm 4.33 \mathrm{~kg} \mathrm{ha}^{-1}\end{array}$} \\
\hline
\end{tabular}

Note: STV $\mathrm{KMnO}_{4}-\mathrm{N}$ - Soil test values of available nitrogen, $\mathrm{STV}_{2} \mathrm{O}_{5^{-}}$- Soil test value for available phosphorus, STV $\mathrm{K}_{2} \mathrm{O}$ - Soil test value for potassium, FN Req. - Fertilizer nitrogen required, $\mathrm{FP}_{2} \mathrm{O}_{5}$ Req.- Fertilizer phosphorus required, $\mathrm{FK}_{2} \mathrm{O}$ Req. - Fertilizer potassium required. 
Table.5 Comparison of STCR and STL approach of fertilizer recommendation of the targeted yield of $33 \mathrm{t} \mathrm{ha}^{-1}$ of cabbage under fertigation

\begin{tabular}{|c|c|c|c|c|c|c|c|c|}
\hline $\begin{array}{c}\text { STV } \\
\mathrm{KMnO}_{4}^{-} \\
\mathrm{N} \\
\left(\mathrm{kg} \mathrm{ha}^{-1}\right)\end{array}$ & $\begin{array}{c}\text { STCR } \\
\text { F. N. Req. }\end{array}$ & $\begin{array}{l}\text { STL } \\
\text { F. N. } \\
\text { Req. }\end{array}$ & $\begin{array}{c}\text { STV } \\
\mathrm{P}_{2} \mathrm{O}_{5} \\
\left(\mathrm{~kg} \mathrm{ha}^{-1}\right)\end{array}$ & $\begin{array}{c}\text { STCR } \\
\text { F. } \mathbf{P}_{2} \mathrm{O}_{5} \\
\text { Req. }\end{array}$ & $\begin{array}{c}\text { STL } \\
\text { F. } \mathbf{P}_{2} \mathbf{O}_{5} \\
\text { Req. }\end{array}$ & $\begin{array}{c}\text { STV } \\
\mathrm{K}_{2} \mathrm{O} \\
\left(\mathrm{kg} \mathrm{ha}^{-1}\right)\end{array}$ & $\begin{array}{c}\text { STCR } \\
\text { F. } \\
\text { K2 OReq. }\end{array}$ & $\begin{array}{c}\text { STL } \\
\text { F. K2O } \\
\text { Req. }\end{array}$ \\
\hline \multicolumn{3}{|c|}{ With sheep manure $\left(25 \mathrm{t} \mathrm{ha}^{-1}\right)$} & & \multicolumn{2}{|c|}{$\begin{array}{l}\text { With sheep manure } \\
\qquad\left(25 \mathrm{tha}^{-1}\right)\end{array}$} & & \multicolumn{2}{|c|}{$\begin{array}{l}\text { With sheep manure } \\
\qquad\left(25 \mathrm{t} \mathrm{ha}^{-1}\right)\end{array}$} \\
\hline 250 & 85.61 & 175.00 & 15 & 79.97 & 125.00 & 110 & 108.90 & 162.50 \\
\hline 260 & 84.41 & 175.00 & 17 & 79.72 & 125.00 & 120 & 107.78 & 162.50 \\
\hline 270 & 83.20 & 175.00 & 19 & 79.47 & 125.00 & 125 & 107.22 & 162.50 \\
\hline 280 & 81.99 & 150.00 & 21 & 79.22 & 125.00 & 130 & 106.66 & 125.00 \\
\hline 290 & 80.78 & 150.00 & 23 & 78.97 & 100.00 & 140 & 105.54 & 125.00 \\
\hline 300 & 79.57 & 150.00 & 25 & 78.72 & 100.00 & 150 & 104.42 & 125.00 \\
\hline 320 & 77.15 & 150.00 & 30 & 78.10 & 100.00 & 160 & 103.30 & 125.00 \\
\hline 340 & 74.74 & 150.00 & 32 & 77.85 & 100.00 & 170 & 102.18 & 125.00 \\
\hline 400 & 67.49 & 150.00 & 35 & 77.47 & 100.00 & 180 & 101.06 & 125.00 \\
\hline 440 & 62.65 & 150.00 & 38 & 77.10 & 100.00 & 200 & 98.83 & 125.00 \\
\hline 480 & 57.82 & 150.00 & 41 & 76.73 & 100.00 & 220 & 96.59 & 125.00 \\
\hline 520 & 52.98 & 150.00 & 44 & 76.35 & 100.00 & 240 & 94.35 & 125.00 \\
\hline 560 & 48.15 & 150.00 & 46 & 76.10 & 100.00 & 260 & 92.11 & 125.00 \\
\hline \multirow[t]{6}{*}{600} & 43.31 & 125.00 & 47 & 75.98 & 100.00 & 280 & 89.87 & 125.00 \\
\hline & & & 50 & 75.60 & 100.00 & 300 & 87.64 & 125.00 \\
\hline & & & 52 & 75.35 & 100.00 & 320 & 85.40 & 87.50 \\
\hline & & & 54 & 75.10 & 75.00 & 340 & 83.16 & 87.50 \\
\hline & & & 58 & 74.60 & 75.00 & 440 & 71.97 & 87.50 \\
\hline & & & 62 & 74.10 & 75.00 & & & \\
\hline
\end{tabular}

Note: STV $\mathrm{KMnO}_{4}-\mathrm{N}$ - Soil test values of available nitrogen, $\mathrm{STV}_{2} \mathrm{O}_{5^{-}}$- Soil test value for available phosphorus, STV $\mathrm{K}_{2} \mathrm{O}$ - Soil test value for potassium, FN Req. - Fertilizer nitrogen required, $\mathrm{FP}_{2} \mathrm{O}_{5}$ Req.- Fertilizer phosphorus required, $\mathrm{F} \mathrm{K}_{2} \mathrm{O}$ Req. - Fertilizer potassium required.

* STCR (soil test crop response) FN, $\mathrm{FP}_{2} \mathrm{O}_{5}$ and $\mathrm{FK}_{2} \mathrm{O}$ recommendations are through soluble fertilizers under fertigation.

** STL (soil testing laboratory) $\mathrm{FN}, \mathrm{FP}_{2} \mathrm{O}_{5}$ and $\mathrm{FK}_{2} \mathrm{O}$ recommendations are through conventional fertilizers through soil application. 
Therefore, targeted yield equations generated from STCR-IPNS technology ensures not only sustainable crop production but also economic use of costly fertilizer inputs.

Under IPNS approach the required dose of fertilizer nutrient was low due to nutrient availability increased by FYM through the mineralization process. Santhi et al., (2011) reported that under integrated plant nutrient system, required dose of fertilizer to achieve desired yield target are reduced due to contribution of nutrients from organic matter through the mineralization process. Similar results were also reported by Basavaraja et al., (2018).These results evidently showed that the fertilizer requirements varied with the varied soil test values for the same level of crop production. Hence, balanced fertilization of soluble fertilizers through soil testing becomes essential for increasing crop production.

The amount of fertilizer nitrogen, phosphorus and potassium required for a fixed yield target of $33 \mathrm{t} \mathrm{ha}^{-1}$ with 25 tons sheep manure ha ${ }^{1}$ through fertigation using soluble fertilizers based on STCR and STL method of fertilizer application was presented in Table 5. As per STL recommendation, fertilizer nitrogen required to achieve a yield target of $33 \mathrm{t} \mathrm{ha}^{-1}$ of cabbage is $150.00 \mathrm{~kg} \mathrm{ha}^{-1}$, if the soil test value is in medium range (280.00and $560.00 \mathrm{~kg} \mathrm{~N}$ $\mathrm{ha}^{-1}$ ), whereas in STCR approach, at lower soil nitrogen level $\left(280.00 \mathrm{~kg} \mathrm{~N} \mathrm{ha}^{-1}\right)$, fertilizer $\mathrm{N}$ through soluble fertilizer required for the same yield target $\left(33 \mathrm{t} \mathrm{ha}^{-1}\right)$ is $81.99 \mathrm{~kg} \mathrm{ha}^{-1}(53.15$ $\%$ reduction over STL approach). At higher soil test value of $560.00 \mathrm{~kg}$ soil nitrogen, just $48.15 \mathrm{~kg}$ of fertilizer nitrogen $(67.90 \%$ reduction over STL approach) through fertigation using soluble fertilizers is needed to achieve the same yield target.

Similarly, for soil test values of phosphorus with medium range (23.00 to $52.00 \mathrm{~kg} \mathrm{P}_{2} \mathrm{O}_{5}$ $\mathrm{ha}^{-1}$ ), the amount of fertilizer phosphorus recommended as per STL is $100.00 \mathrm{~kg} \mathrm{ha}^{-1}$, But, in STCR approach using soluble fertilizers under fertigation it varies between $78.97 \mathrm{~kg}$ to $75.35 \mathrm{~kg}$ of fertilizer phosphorus in medium range of soil test values to achieve targeted yield of $33 \mathrm{t} \mathrm{ha}^{-1}$ of cabbage (Table 4). Similarly, $125.00 \mathrm{~kg} \mathrm{ha}^{-1}$ potassium fertilizer is required to produce $33 \mathrm{t} \mathrm{ha}^{-1}$ of cabbage, when the soil test values are in medium range (130.00 to $300.00 \mathrm{~kg} \mathrm{~K}_{2} \mathrm{O} \mathrm{ha}^{-1}$ ) as per STL recommendations. However, in STCR approach of fertilizer application, $106.66 \mathrm{~kg} \mathrm{ha}^{-1}$ of potassic fertilizer through fertigation using soluble fertilizers needs to be added when the soil test value is $130.00 \mathrm{~kg}$ $\mathrm{K}_{2} \mathrm{O} \mathrm{ha}^{-1}$. But, when the soil test value is $300.00 \mathrm{~kg} \mathrm{~K}_{2} \mathrm{O} \mathrm{ha}^{-1}$, only $87.64 \mathrm{~kg} \mathrm{ha}^{-1}$ potassium through soluble potassic fertilizer is required to achieve the yield target of $33 \mathrm{tha}^{-}$ ${ }^{1}$.This is mainly due to split application of soluble fertilizers through fertigation during their growth period, as and when crop needed under critical stage results in synchrony between cabbage nutrient demand and nutrients applied through fertigation without any nutrient stress situation.

Ultimately, these results will help in the reduction of fertilizer inputs and avoid excessive use of chemical fertilizers. These results are in conformity with the findings of Basavaraja et al., (2018) that fertilizer use by following the STCR targeted yield equations in chilli crop are more economical and environment-friendly. Fertigation using soluble fertilizer through STCR approach helps in the judicious use of nutrients and water without accruing any wastage as compared to STL method of fertilizer prescription.

The findings of the present study clearly revealed that fertilizer prescription equations developed through inorganics or under IPNS using soluble fertilizers through fertigation could be effectively used in Alfisols of 
Karnataka for achieving the specific targeted yield of cabbage under fertigation. The inclusion of IPNS component like sheep manure in the present investigation resulted in reduction in fertilizer nutrient requirement for desired yield targets. STCR approach of fertilizer application specifically through fertigation using soluble fertilizers is found to be superior over STL approach in the efficient use of costly fertilizers in a balanced way without any wastage or under usage of any nutrients to achieve the specific yield target. Thus, STCR approach of fertilizing the crops on yield targets coupled with fertigation using soluble fertilizers appears precise, meaningful, environmentally friendly and needs to be popularized among the farming community.

\section{Acknowledgments}

The author would like to thank the Indian Council of Agricultural Research (ICAR) for providing fellowship as SRF during the research work and AICRP on STCR, UAS, GKVK, Bangalore for providing all facilities for carrying out research.

\section{References}

Basavaraja, P. K., Gangamruth A,G. V., Mohamed Saqeebulla, H. AND Prabhudeva, D. S., 2018, Soil test based fertilizer prescription equation for targeted yield of dry chilli under Alfisols of eastern dry zone of Karnataka, Int. J. Trop. Agric., 36(2): 267-274.

Basavaraja, P.K., Mohamed, S. and Dey, P., 2017, Integrated fertilizer prescription equations for finger millet (Eleusine coracana L.) through inductive cum targeted yield model on an Alfisol, Int.J.Curr.Microbiol.App.Sci., $\quad$ 6(7): 2571-2580.

Deshmukh, G. and Hardaha, M.K., 2014, Effects of irrigation and fertigation scheduling under drip irrigation in papaya. J. Agric. Search., 1(4): 216220.

FAO, 2000, Statistical database food and Agricultural Organization of the United Nations, Rome, Italy.

Jackson, M. L., 1973, Soil Chemical Analysis. Prentice Hall of India Pvt. Ltd., New Delhi.

Kasthuri Thilagam, V. and Natesan, R., 2009, Fertilizer prescription equations for desired yield targets of cauliflower under integrated plant nutrient system based on targeted yield model, Agric. Sci. Dig., 29(4): 250-3.

Meena, A. M., Raizuddinahmed, S., Chandrasekhara Reddy., Prasad and Rao, B. R. C., 2001, Soil test crop response calibration studies on onion (Allium cepa) in Alfisols. J. Indian Soc. Soil Sci., 49(4): 709-713.

Milap C, Benbi, D. K. and Benipal, B. S., 2006, Fertilizer recommendations based on soil tests for yield targets of mustard and rape seed and their validations under farmer's field conditions in Punjab. J. Indian. Soc. Soil Sci., 54(3): 316-321.

Ramamoorthy, B., Narasimhan, R. L. and Dinesh, R. S., 1967, Fertilizer application for specific yield targets of sonara-64, Indian farming, 5: 43-45.

Ray, P. K., Jana, A. K., Mitra, D. N., Saha, M. N., Chaudhary, J., Saha, S. and Saha, A. R. 2000, Fertilizer prescription on soil test basis for jute, rice and wheat in a Typic Ustochrept, J. Indian. Soc. Soil Sci., 48: 79-84.

Santhi, R., Bhaskaran, A. and. Natesan, R. 2011, Integrated fertilizer prescriptions for beetroot through inductive cum targeted yield model on an Alfisol, Commun. Soil Sci. Pl. Analy., 42: 1- 8.

Smitha John, K., Santhi, R., Natesan, R. and Gayathri, A., 2010, Soil test based fertilizer prescription under integrated 
plant nutrition system for cabbage on Inceptisol of Tamil Nadu, Ad. Plant sci., 23(1): 155-157.

Uma Devi, R. 2005, Soil test crop response correlation studies under integrated plant nutrition system for carrot on Alfisols, M.sc (Agri) Thesis, TNAU,
Tamil Nadu, India.

Vijayalakshmi, K., 2008, Soil test crop response studies on radish under integrated plant nutrition system. M.Sc. (Agri.) Thesis, TNAU, Tamil Nadu, India.

\section{How to cite this article:}

Sundaresh, R. and Basavaraja, P.K. 2019. Soil Test Based Fertilizer Prescription for Targeted Yield of Cabbage (Brassica oleracea Var. Capitata) under Fertigation using Soluble Fertilizers. Int.J.Curr.Microbiol.App.Sci. 8(11): 1371-1383.

doi: https://doi.org/10.20546/ijcmas.2019.811.160 